\title{
Building High Performing Schools
}

\author{
Kapil Pandla" ${ }^{1 *}$ and Nidhi Gupta ${ }^{2}$ \\ ${ }^{1}$ Associate Professor, (HR \& OB), IMI Bhubaneswar, Bhubaneswar - 751003, Odisha, India; \\ kapilpandla@gmail.com \\ 2IMI Bhubaneswar, Bhubaneswar - 751003, Odisha, India; \\ nidhigupta1176@gmail.com
}

\begin{abstract}
Education is most important driver for success of any nation. Therefore, quality of education and its delivery can be a key predictor of success of any society. In spite of good infrastructure and excellent financial backing many schools do not find place in league of top schools. It is a known fact that the present school system is radically different from the model followed in the past. This shift has brought lots of challenges to the Management, Principals, Teachers, staff and other stakeholders. This study is aimed at understanding challenges faced by Indian schools and identifying drivers for high performance in school education.
\end{abstract}

Keywords: High Performance, Instructional Leadership, Schools, School Management

\section{Prelude}

Historically, Indian Education System has been elitist. Traditional education was customized to the needs of the Brahmin boys and son of the royal families who were taught to read and write by a teacher known as Guru. British rule also reinforced the same kind of arrangements for the privileged section of the society.

In early twentieth century some other castes also realized the advantages of education as a passport to political power and acquire the formal learning (Cheney et al., 2005)

The constitution makers realized the importance of education therefore made it as fundamental right. In addition to this being a fundamental right of every citizen, it is also increasingly evident that a robust, inclusive and high quality system of school education is essential for social and economic development (NKC, 2007)

It was resolved by the framers of the constitution that the new Indian state would endeavour to provide free and compulsory education to all children up to age 14 by
1960. This goal turned out to be elusive and the deadline for its achievement has been put back repeatedly in the past so many years. While even today this goal remains unfulfilled, there has been very encouraging progress in schooling participation and other educational outcome indicators in recent times (Kingdon, 2007).

The Constitution (Eighty-sixth Amendment) Act, 2002 inserted Article 21-A in the Constitution of India to provide free and compulsory education of all children in the age group of six to fourteen years as a Fundamental Right in such a manner as the State may, by law, determine. The Right of Children to Free and Compulsory Education (RTE) Act, 2009, which represents the consequential legislation envisaged under Article 21-A, means that every child has a right to full time elementary education of satisfactory and equitable quality in a formal school which satisfies certain essential norms and standards.

The RTE Act, 2009 further lay down norms regarding teacher pupil ratio, building and infrastructure, qualification of teachers etc. These provisions along with guidelines from the affiliating boards of education (CBSE and

${ }^{*}$ Author for correspondence 
state boards) the management of schools has become a herculean task for Principals, Teachers, Staff, Parents and Other stakeholders.

\section{Major Aspects and Challenges in Managing Schools}

Decentralization of the management of schools, combined with community participation, is the most effective instrument for ensuring accountability, improving the day-to-day functioning of schools and allowing for flexible responses to local requirements. Therefore, there should be devolution of authority to local levels, whether to panchayats, Village Education Committees or Municipalities. School Management Committees that include representatives of all stakeholders, including parents and teachers, should be empowered to make many decisions. Social audits of schools should be supported and encouraged. (NKC Report, 2007).

Active community participation and changing dimensions in school education have thrown some real challenges in management of schools. Some of these challenges are

\subsection{Maintenance and Infrastructure Management}

Creating infrastructure and maintaining the same is a big task for School Management. According to $7^{\text {th }}$ All India School Education Survey (AISES) 19.2\% of primary school in the country are running in non pucca buildings, $20 \%$ of the schools do not have drinking water facilities, nearly $66 \%$ of the primary schools don't have urinals and lavatory, only $48 \%$ of the schools have playground facilities. The survey also revealed that schools do not have adequate number of blackboards and furniture. The figures were slightly better for private schools. In the backdrop of the above, when we are talking about quality education, the above mentioned figures are real handicap and pose a big challenge for the school management.

\subsection{HR Management (Teaching and Non Teaching)}

Managing people has always been an important factor in success of any organisation and educational institutes are no exception. Typical HR function in Schools may include activities like

1. Supervising and evaluating teaching and non teaching staff.

2. Funding and Arranging for teacher training programmes.

3. Hiring and firing of teaching and non teaching staff mainly in private schools.

4. Paying salaries and incentives.

5. Keeping a check on absenteeism, grievances, etc. and taking appropriate actions especially in Government and Government Aided Schools.

6. Teachers Commitment and continuous zeal of learning.

Equally worrying perhaps is evidence of teacher negligence in schools. Firstly, teacher absence rates are high (Kingdon, 2007). Kremer et al., (2005) survey of teacher absence in rural India in 2003 made three unannounced visits to each one of 3700 schools in 20 major states of India. They found that, on average, 25 percent of teachers in government primary schools were absent from school on a given day. Secondly, and more disturbingly, even among teachers who were present, only about half were found engaged in teaching.

\subsection{Budget}

A study conducted by the Centre for Civil Society, New Delhi, in 2005 (Singh, 2006), stressed that the major problem lay not in the level of financial allocations, but rather in the organizational inefficiencies, lack of accountability and mis-utilization of funds. The effectiveness of education depends largely on how well its units of service are managed. Education can be made more relevant to the user through incorporating professional management at school level. The National Knowledge Commission of India (2007) has proposed to encourage decentralization, local autonomy in management of schools, flexibility in disbursal of funds to improve quality and generate accountability.

The problems related to finances are not only with Government and Government Aided School but also with the private schools.

\subsection{Curriculum and Pedagogy}

Curriculum reform remains a critically important issue in almost all schools. School education must be made more 
relevant to the lives of children. There is need to move away from rote-learning to understanding concepts, developing good comprehension and communication skills and learning how to access knowledge independently. This also requires substantial changes in the examination system, especially at Board level but also earlier. (NKC Report, 2007).

To improve quality of learning, CBSE brought in major reforms in examination system by introducing Continuous Comprehensive Evaluation in 2009.

Continuous and Comprehensive evaluation refers to a system of school based assessment that covers all aspects of student's development.

It emphasizes two fold objectives.

1. Continuity in evaluation and assessment of broad based learning.

2. Behavioral Outcome.

\section{Continuous}

1. Continual - from the beginning and during the instructional process

2. Periodicity- frequency/term

\section{Comprehensive}

1. Scholastic - Subject specific areas.

2. Co-Scholastic - Life skills, attitudes and values and other co curricular activities.

Includes a variety of tools and techniques for assessment of the learners.

It involves activities like collaborating project and research work in groups and balancing scholastic and co-scholastic areas.

(Source: www.cbse.nic.in/cce/index.html)

\subsection{Monitoring and Evaluation}

Education as a critical service sector and the agencies of education, a critical face of this angle, has been suffering from lack of professional management (Prabhakar \& Rao, 2011).

There is no proper monitoring and evaluation of administrative activities in most of the schools.

\subsection{Technology and its usage}

David Bennett, an educational consultant suggests that the school of the future will be radically different from the model of the last 130 years, technology alone will ensure that. It is a proven fact that technology enhances learning but it also brings some ill effects. Therefore it becomes all the more important for School Management to strike a balance.

There is a buzz about smart classrooms equipped with technology that supports learning but if reality is there are schools in the country which are still not having adequate number of blackboards.

The point is if schools can overcome these challenges and convert them into opportunity can they become High Performing Schools.

\section{Key Actors in School Management and their Changing Roles}

There are three key actors as far as management of schools is concerned namely Principal, Teachers and Parents. Generally management of school revolves around the head of school/Principal.

\subsection{Head of School/Principal}

Teachers teach and work in schools that are usually administered by managers, often known as principals or headmasters. School administration is itself often part of larger administration units. The conditions of teachers' working life are influenced by the administration and leadership provided by principals, and it is widely assumed that school leadership directly influences the effectiveness of teachers and the achievement outcomes of students (e.g. Hallinger and Murphy, 1986; OECD, 2001; Pont, Nusche and Moorman, 2008).

CBSE under its Affiliation Bye Laws listed around 26 points on the functions of school principals which includes academic planning, financial management, monitoring work of teachers and non teaching staff, managing school resources, sharing the school report with Parents, organizing co-curricular and extra-curricular activities, conduct physical check and verification of school stock, assessment of teaching activities etc.

But whether Principal role is confined to administrative manager? The answer is big no. There is big change in the role from administrative manager to instructional leader.

Instructional leadership differs from that of a school administrator or manager in a number of ways. Principals who pride themselves as administrators are too preoccupied in dealing with strictly administrative duties compared to principals who are instructional leaders. 
The latter role involves setting clear goals, allocating resources to instruction, managing the curriculum, monitoring lesson plans, and evaluating teachers. In short, instructional leadership is those actions that a principal takes, or delegates to others, to promote growth in student learning (Flath, 1989)

OECD Report 2009 argues that to meet the educational needs of the $21^{\text {st }}$ century the principals in primary and secondary schools must play a more dynamic role and become far more than an administrator of top-down rules and regulations. Schools and their governing structures must let school leaders lead in a systematic fashion and focus on the instructional and learning processes and outcomes of their schools. The focus should be on learning outcomes of the students.

Jamentz (2002) notes that simply having a list of essential teaching skills is not enough "instructional leaders must internalize exemplars of effective classroom practice so that they can make accurate judgment about, and give useful feedback to, the teachers with whom they work".

With the changing role it has become very important that school principals should be trained to become instructional leaders.

\subsection{Teachers}

Second important pillar in school education is teachers. If we go by history teachers have been considered as supreme authority in terms of knowledge and always carried most honorable position in the society. They act as a mentor to the students and should guide their students to become leaders for tomorrow.

Pandla, Sharma and Gupta (2009) argued that even though large number of schools, parents and CEOs felt the importance of mentoring at school level to create leaders for tomorrow yet there was no formal provision of mentoring in many schools. Many of the respondents felt that proper training to the teachers can make them good mentors.

Teaching in school has always been a challenging task but with the recent changes in the school education system has made the job of teachers even more demanding.

It is a common perception that assessment on regular basis under the Continuous and Comprehensive
Evaluation has increased the teacher's workload. It has been many years since the scheme has been introduced in India, but teachers still seem to be grappling with the process. The teachers find themselves under tremendous stress although they believe that the system is student centric but there is lot of clerical work required.

\subsection{Parents}

As discussed above National Knowledge Commission advocated the involvement of parents in school management. This arrangement is made in the Affiliation Bye-laws of CBSE to have parent of the student as member of school management committee.

The idea may be to improve student achievement, close monitoring of school staff and efficient use of resource. This will also make teachers put the children's welfare before their own; that human, financial, and material resources will flow into the school by virtue of the parental support; and that more children will learn, both at home and in the community. (SBM, Human Development Network, 2007)

But if these provisions are not implemented properly the results won't be encouraging. Sadananda \& Chandrasekhar (2008) found that in the State of Karnataka, all government schools have School Development Monitoring Committees; each comprising of nine members from parents and community representing women and other disadvantaged groups, as per the government guidelines. But, regarding the frequency of meetings, the study found that all members do not take part and none of the schools had conducted any meeting for the last six months and around ten percent of the schools have not even maintained any records about the meetings.

In a number of diverse country such as Papua New Guinea, India, and Nicaragua, parental participation in school management has reduced teacher absenteeism (Partinos and Kagia, 2007; Karim et al., 2004)

Therefore the importance of these committees in managing schools must be communicated to all the stakeholders and parents should be encouraged to actively participate.

Whether these actors are drivers for high performing schools? 


\section{Drivers of High Performing Schools}

Research is still non-conclusive of the fact that why some Organisations in the same industry performs consistently so well but others with the same set of opportunities can't (Pandla K, 2016). This holds true even for the education institutions. It becomes all the more difficult in case of schools where student success is sole parameter for measuring performance.

Unique characteristics of the majority of effective schools are correlated with student success. Because of this, these characteristics are called correlates by researchers (Lezotte 1991). The seven common correlates include: Clear school mission, high expectations for success, instructional leadership, opportunity to learn and time on task, safe and orderly environment, positive home-school relations, and frequent monitoring of student progress.

According to Kannapel et al. (2005) following eight characteristics differentiate high performing schools from low performing schools are belief that all students can succeed at high levels, High expectations, Collaborative decision making, Teachers accept their role in student success or failure, Strategic assignment of staff, Regular teacher-parent communication, Caring staff and faculty, Dedication to diversity and equity.

According to MASB (2015) major characteristics of high performing schools are Clear and Shared Focus, High Standards and Expectations for all Students, Effective School Leadership, High Levels of collaboration and Communication, Curriculum, Instruction and Assessment Aligned With Standards, Frequent Monitoring of Teaching and Learning, Focused Professional Development, Supportive Learning Environment.

Three drivers of high performing organisations are Organisational factors (Design, Continuous improvement, Culture, Resources, and Strategy), People Factors (Commitment, Competence, Participation and Involvement) and Leadership factors (Long Term Orientation, Development of future leaders, External Orientation) (Pandla K., 2016).

According to Lezotte (1991) there is a clearly articulated school mission in effective schools and onus is on principal to create a school mission (Haberman, 2003). The principal is not the sole leader; he or she is a "leader of leaders" (Lezotte, 1991). Therefore Leadership factor is one major driver in High Performing schools

\section{Proposed model}

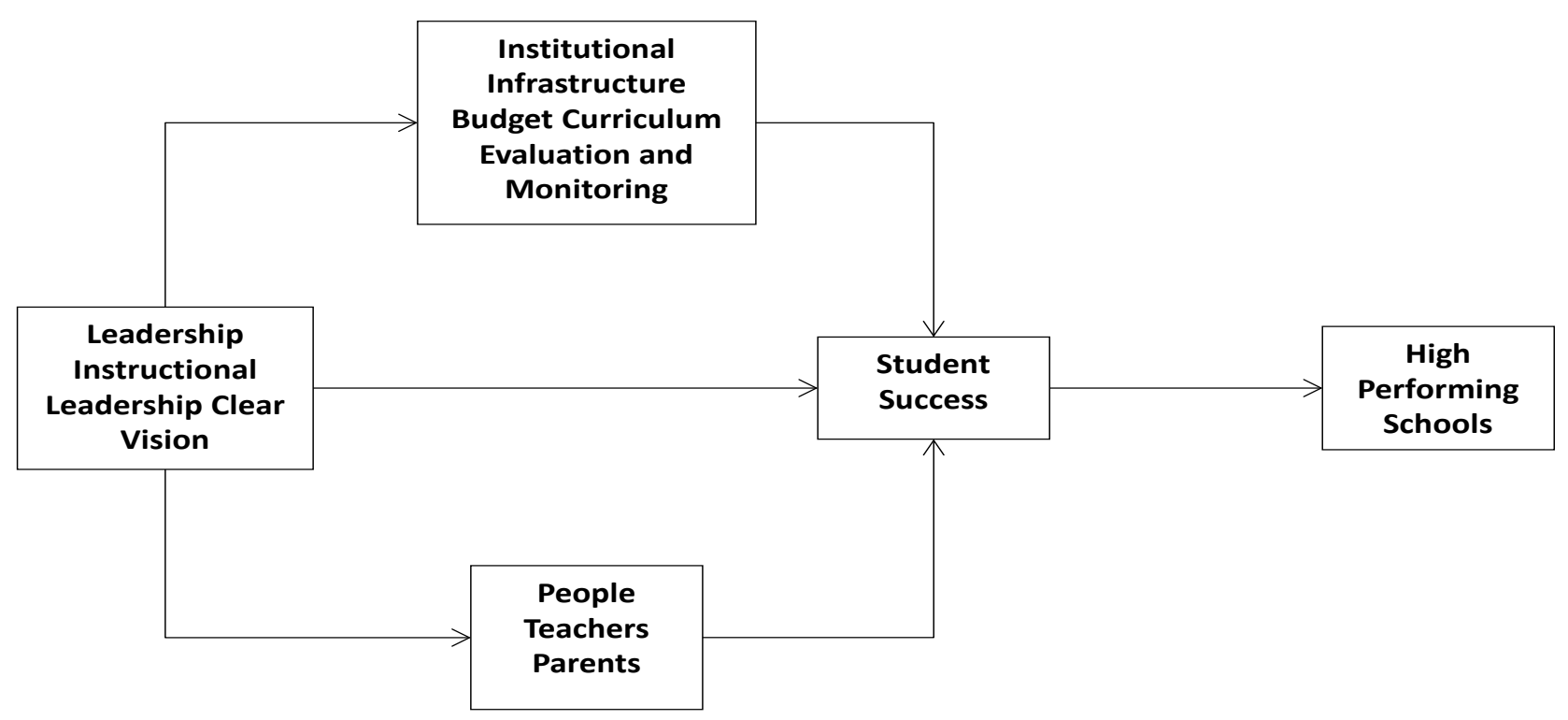

Drivers of High Performing Schools. 
Teachers should be partners with the principal in creating that vision (Cibulka and Nakayama, 2000). According to Hattie (2003) after accounting for factors individual to the student (prior learning, home background etc), the teacher has by far the largest impact on learning (about $30 \%$ of the variance).

Teachers commitment is utmost important in driving schools towards high performance.

Parents understand and support the basic mission of the school and are given opportunities to play important roles in helping the school to achieve its Mission (Lezotte, 2001).

Therefore positive parent-school relationship brings effectiveness in schools.

ApartfromaboveInstitutionalfactorslike infrastructure, budget, Curriculum, Instruction and Assessment Aligned With Standards (MASB, 2015), positive teaching and learning environment, proper evaluation and monitoring can lead schools to High Performance.

\section{Discussion}

It is evident from the study that there is quantum shift in school education. More and more formal community participation, introduction of Continuous Comprehensive Evaluation, changes in pedagogy and curriculum, ever changing needs of the students is posing a huge challenge to all the stakeholders of school management.

It was discussed that if schools overcome these challenges they can become effective schools.

It was also argued in the study that School Leadership, Teachers, Infrastructural support and positive parentschool relations are key drivers in student success which is considered as sole indicator for High Performing Schools.

\section{Future Research}

In future study can be done to establish indicators of student success and testing the proposed model.

\section{References}

1. Bennett, D. The school of the future: key issues for school leaders, National College for School Leadership. Available from: www.educationalleaders.govt.nz retrieved on 22.07.2020
2. Cheney, R.R., Ruzzi, B.B., \& Muralidharan, K. (2005). A profile of Indian Education System, National Center on Education and the Economy.

3. Cibulka, J., \& Nakayama, M. (2000). The creation of high performance schools through organizational and individual learning: A practitioner's guide to learning communities. As mentioned in Effective Schools, Pearson. Available from: https://images.pearsonassessments.com/images/ tmrs/tmrs_rg/EffectiveSchools.pdf?WT.mc_id=TMRS_ Effective_Schools retrieved on Nov, 2017

4. CBSE- Affiliation Bye Laws. Available from: www.cbse.nic. in/affili 1/aff.pdf

5. Flath, B. (1989). The principal as instructional leader. ATA Magazines, 69(3), 19-22, 47-49.

6. Haberman, M. (2003, October 23). Creating effective schools in failed urban districts. http://www.educationnews. org/creating-effective-schools-in-failed.htm as cited in Effective Schools, Pearson, retrieved on 22nd July 2020 from http://images.pearsonassessments.com/images/tmrs/ tmrs_rg/EffectiveSchools.pdf

7. Hallinger, P. \& Murphy, J. (1986, April). The Superintendent as Instructional Leader. Paper presented at the annual meeting of the American Educational Research Association (AERA), San Francisco.

8. Hattie, J.A.C. (2003, October). Teachers make a difference: What is the research evidence? Paper presented at the Building Teacher Quality: What does the research tell us ACER Research Conference, Melbourne, Australia. Available from:

9. http://research.acer.edu.au/research_conference_2003/4

10. Education, What Is School -Based Management, Human Development Network. Available from: http:// siteresources.worldbank.org/EDUCATION/Resour ces/278200-1099079877269/547664-1099079934475/ 547667-1145313948551/what_is_SBM.pdf

11. Jamentz, K. (2002) Isolation is the Energy of Improvement; Instructional Leadership to support standard - Based practice. San Francisco; West Ed, 2002; p. 109

12. Kannapel, P. J., \& Clements, S. K., with Taylor, D., \& Hibpshman, T. (2005). Inside the black box of highperforming high-poverty schools. Lexington, KY: Prichard Committee for Academic Excellence. Available from: http://www.prichardcommittee.org/Ford\%20Study/ FordReportJE.pdf.

13. Karim, S., C. A. Santizo Rodall, \& E. C. Mendoza (2004). Transparency in Education. International Institute for Educational Planning and International Academy of Education. Paris and Brussels: UNESCO

14. Kingdon Geeta Gandhi (2007). The Progress of School Education in India. Economic and Social Research 
Council-Global Poverty Research Group Working Paper 071. Oxford University Press, London. p. 1- 6.

15. Kremer, M., Chaudhury, N. \& Rogers, F. H., Muralidharan, K. \& Hammer, J. (2005). Teacher absence in India: A Snapshot. Journal of the European Economic Association. 3(2-3), 658-667.

16. Lezotte, L. (1991). Correlates of effective schools: The first and second generation. Okemos, MI: Effective Schools Products, Ltd.

17. Lezotte, L. (2001). Revolutionary and evolutionary: The effective schools movement. Okemos, MI: Effective Schools Products, Ltd.

18. MASB, Building Blocks of High-Performing Schools. (2015). Available from: http://www.masb.org/building-blocks-ofhigh-performing-schools.aspx\#sthash.3oXejZxX.dpbs

19. National Knowledge Commission, Recommendation on School Education. (2007). Available from: http:// knowledgecommission.gov.in/downloads/documents/ nkc_se.pdf

20. Kapil, P., Sharma, M. \& Gupta, P. (2009). Mentoring at elementary education and creating leaders for tomorrow, Paper presented at International Conference on Educational Leadership, IIM Bangalore
21. Pandla, K. (2016). Drivers and characteristics of high performing organizations. International Journal of Business and Administrative Studies, 2(3), 78-82. https:// doi.org/10.20469/ijbas.2.10001-3

22. Patrinos, H., \& Kagia, R. (2007). Maximizing the Performance of Education Systems: The Case of Teacher Absenteeism. In The Many Faces of Corruption-Tracking Vulnerabilities at the Sector Level, ed. J. E. Campos and S. Pradhan. Washington, DC: World Bank.

23. Pont, B., Nusche, D. \& Moorman, H. (2008). Improving School Leadership, Policy and Practice, OECD, Paris.

24. Prabhakar, N.P. \& Rao, K.V. (2011). School based management: an analysis of the Planning framework and community participation. Researcher World -Journal of Arts, Science and Commerce, 2(3), 107.

25. OECD. (2009). Leading to Learn: School Leadership and Management Styles, Creating Effective Teaching and Learning Environments: First Results from TALIS

26. OECD Education Policy Analysis. (2001). Available from: http://www.educarchile.cl/medios/20020108113337.pdf

27. Singh, A. (2006). Public Sector Education in India: Challenges Ahead. University of Delhi, New Delhi.

28. Seventh All India School Education Survey. Available from: www.ncert.nic.in/.../pdfs/Schools_Physical_Ancillary_ Facilities.pdf

29. Sadananda JS, Chandrasekhar E. (2008). Decentralisation in education in Karnataka. Indian Educational Review, 44(2), 143-7. 